\title{
Improvement and application of hole-sealing technology across seams in Song Zao coal mine
}

\author{
Rili Yang ${ }^{1,}$, Xiaoxia Zhao ${ }^{2}$, Lan $\mathrm{Yu}^{1}$ \\ ${ }^{1}$ School of Energy Engineering, Long-Dong University, Qing'yang745000, China \\ ${ }^{2}$ China Coal Technology and Engineering Group Chongqing Research Institute, Chongqing400037, China
}

\begin{abstract}
Through the analysis on the drilling hole gas drainage effect(2225 working face crossing seam drainage, $\mathrm{K}_{2}$ air way drilling field layout, crossing seam drainage gas in $\mathrm{K}_{3}{ }^{\mathrm{b}}$ coal seam), it is found that hole sealing technology directly affects gas drainage. Based on the original hole sealing technology and combining with field conditions, an improved drilling scheme for transportation roadway was proposed, considering the drilling layout, sealing material and depth, grouting time, pre-plunging depth. Test results of the scheme showed that, with a rise in the cost and drilling pressure relief time, the pressuring-relief gas drainage amount was greatly increased, the drilling field pre-pumping concentration was enhanced to 4.4times, the drainage efficiency was improved.
\end{abstract}

\section{Introduction}

Coal and gas outburst is one of the most serious factors in mine safety production ${ }^{[1]}$. As for the gas and outburst coal mines, it is necessary to control regional gas before extraction and mining of the working face ${ }^{[2]}$. At present, traditional lower gas pre-drainage concentration and less obvious drainage effect seriously restrict methane utilization and mine production schedule, and the lower concentration is caused with backward hole-sealing technology ${ }^{[3-4]}$. There are scholar proposed that different gas drainage design schemes ${ }^{[5]}$ combined fundamental theorieds with the fact, some improved process to increase the gas pre-drainage concentration ${ }^{[6]}$, gas drainage drilling holes' radial and the holes layout ${ }^{[7-8]}$. According the Song Zao coal mine fact, this paper proposed holes layout, hole-sealing technology which is beneficial to safe production.

\section{Existing $K_{3}{ }^{b}$ through holes sealing process and problems}

The $\mathrm{K}_{3}{ }^{\mathrm{b}}$ coal seam borehole of Song zao Mine was drilled in the drilling of $K_{2}$ roadway. The specific sealing method was as follows: a DN40mm return plastic pipe with a length of $8 \mathrm{~m}$ and a DN15mm grouting plastic pipe with a length of $6 \mathrm{~m}$ were fed into the drill hole. In the $0.5 \mathrm{~m}$ section of the orifice, bundle the grouting pipe and the return pipe with the cotton yarn and use the Mali bulk to inflate the pre-plugging hole. After the pre-blocking is completed for one day, the grouting pump is used to inject the slurry into the hole two times at intervals of one day. The materials are cement, Water does not leak, gypsum (ratio10:1:1), mixture (feed water mixing ratio is controlled at 2.5:1).

In the working face of $\mathrm{K}_{2}$ coal seam, the roof management adopts the slow sinking method during the mining process. The transportation lanes and return airway is following the mining process. With the promotion of the $\mathrm{K}_{2}$ coal seam working face and the not enough depth of the original sealing hole, the borehole section of the layer is in the $\mathrm{K}_{2}$ falling zone, and the falling zone destroys the tightness of the borehole plugging. At the same time, as for the plastic pipes that used to seal the holes in the transportation lane and the wind lane, whose strength is small and are easily blocked by extrusion deformation. Drilling gas gushing out of the channel leads to a short time for the pressure relief of the borehole, a small amount of drainage, and a poor drainage effect. The following is an example of the 2\# drill field at No.2225, shown as Table 1. As can be seen from the below table, the time for relieving pressure pumping at No. $6 \#$ of the No. 2225 return airway is short, only 33 days, and the accumulated amount of extraction is $526,000 \mathrm{~m}^{3}$. 
Table 1.Pressure Relied Gas Drainage Effect at No.2225 Return Airway in 6\# Drilling Field

\begin{tabular}{|c|c|c|c|c|c|c|c|c|}
\hline $\begin{array}{l}\text { Sealing } \\
\text { process }\end{array}$ & $\begin{array}{l}\text { Test } \\
\text { date }\end{array}$ & $\begin{array}{l}\text { Drainage } \\
\text { days }\end{array}$ & $\begin{array}{c}\text { Gas } \\
\text { concentration }\end{array}$ & $\begin{array}{c}\text { Negative } \\
\text { pressure } \\
(\mathrm{Pa})\end{array}$ & $\begin{array}{c}\text { Flow } \\
\left(\mathbf{m}^{3} / \mathbf{m i n}\right)\end{array}$ & $\begin{array}{c}\text { Extraction } \\
\text { amount } \\
\left(\mathbf{m}^{3}\right)\end{array}$ & $\begin{array}{c}\text { accumulated } \\
\text { amount } \\
\left(\mathbf{m}^{3}\right)\end{array}$ & Note \\
\hline \multirow{5}{*}{$\begin{array}{l}\text { Plastic } \\
\text { tube } \\
\text { sealing } \\
\text { hole }\end{array}$} & 5.20 & \multirow{5}{*}{33} & $82 \%$ & 2773 & 14 & 211608 & 211608 & $\begin{array}{c}\text { Pressure relief initial } \\
\text { measurement }\end{array}$ \\
\hline & 5.30 & & $90 \%$ & 2793 & 15.39 & 188352 & 399960 & \\
\hline & 6.9 & & $63 \%$ & 2394 & 10.77 & 100728 & 500688 & \\
\hline & 6.22 & & $25 \%$ & 1463 & 3.22 & 25560 & 526248 & $\begin{array}{l}\text { Pressure relief pumping } \\
\text { last measurement }\end{array}$ \\
\hline & 7.28 & & $9 \%$ & 532 & 0.33 & & & Residual pump \\
\hline
\end{tabular}

\section{Hole sealing across layer $s$ improvement test site}

The test area is selected from the return airway at 2225 coal working face, and the 2225 face is located between the N1\# and S2\# stone gates in the second level two mining area +100 to +175 stages, and the working surface elevation is between +106.0 and $+177.7 \mathrm{~m}$. . 2225 east of working face is 2223 working face (having been mined), south is 2210-2 working face (having been mined), west is the isolation pillar between the second level and the third level, and the north is the fault isolation pillar. The bottom $\mathrm{K}_{1}$ coal seam and the top $\mathrm{K}_{3}{ }^{\mathrm{b}}$ coal seam were not mining. The $\mathrm{K}_{3}{ }^{\mathrm{b}}$ coal seam is stable and has a simple structure. The distance from the $\mathrm{K}_{3}{ }^{\mathrm{a}}$ coal seam is 1.08 to $5.43 \mathrm{~m}$, with an average of $2.98 \mathrm{~m}$, and the distance from the $\mathrm{K}_{4}$ seam is 6.3 to $12.4 \mathrm{~m}$, with an average of $8.81 \mathrm{~m}$. The total thickness of the coal seam is 0.97 to $4.06 \mathrm{~m}$, average $2.41 \mathrm{~m}$, and generally 2.00 to $3.20 \mathrm{~m}$ thick. The coefficient of variation $(\gamma)$ of coal thickness is $21 \%$, and the recoverability index $(\mathrm{km})$ is 1 . It is a stable coal seam. The roof is mudstone and sandy mudstone, partially siltstone; the floor is dominated by clay rock and the part is fine sandstone.

No.2225 Return airway drilling site (Main Shihmen S1\# crosscut) is arranged in a depth of $20 \mathrm{~m}$ from the floor of K3b coal seam every $75 \sim 100 \mathrm{~m}$. Construction of gas drainage drilling in $\mathrm{K} 3 \mathrm{~b}$ coal seam in drill yard Holes and boreholes are fan-shaped, and the distance and inclination of the final hole spacing are both $10 \mathrm{~m}$. Each borehole controls the drilling field in the north and south of the K3b coal seam 30 to $50 \mathrm{~m}$. The inclination of the hole is between $-3^{\circ}$ and $81^{\circ}$, and the hole depth is between 16 and $60 \mathrm{~m}$. The plane layout of the gas drilling in $\mathrm{K}_{2} \mathrm{~b}$ coal seam of No.2225 mining face is shown in Fig 1.

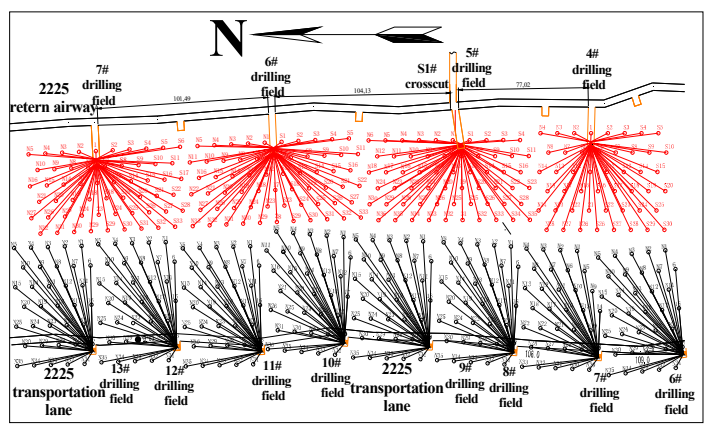

Fig 1 Drill Holes Arrangement for 2225 Mining Face

\section{Holes sealing process improvement test across layer}

\subsection{Transportation hole drilling field holes sealing improvement scheme}

$\mathrm{K}_{3} \mathrm{~b}$ through hole in the transportation lane drilling field adopts the iron pipe sealing hole and the sealing hole covers the falling belt.

(1) Determination of sealing depth: According to investigation, after mining of the $\mathrm{K}_{2} \mathrm{~b}$ protective layer of the mine, the falling belt is 7 times heightened, and all drilling holes in the transportation lane pass through the falling zone, as shown in Fig. 2 . Each drilling field of the transportation lane has a trend of about $50 \mathrm{~m}$ or so and is about $50 \mathrm{~m}$ in length. A total of 5 rows 6 columns of drill holes are arranged. According to the requirements of the drilling holes sealing are across the falling belts, the depth of the first column of drilling holes is calculated $46 \mathrm{~m}$ and the second is $36 \mathrm{~m}$., the third column is $26 \mathrm{~m}$, the fourth column is $16 \mathrm{~m}$, and the depth of the first column is $10 \mathrm{~m}$. as Fig 2 shows.
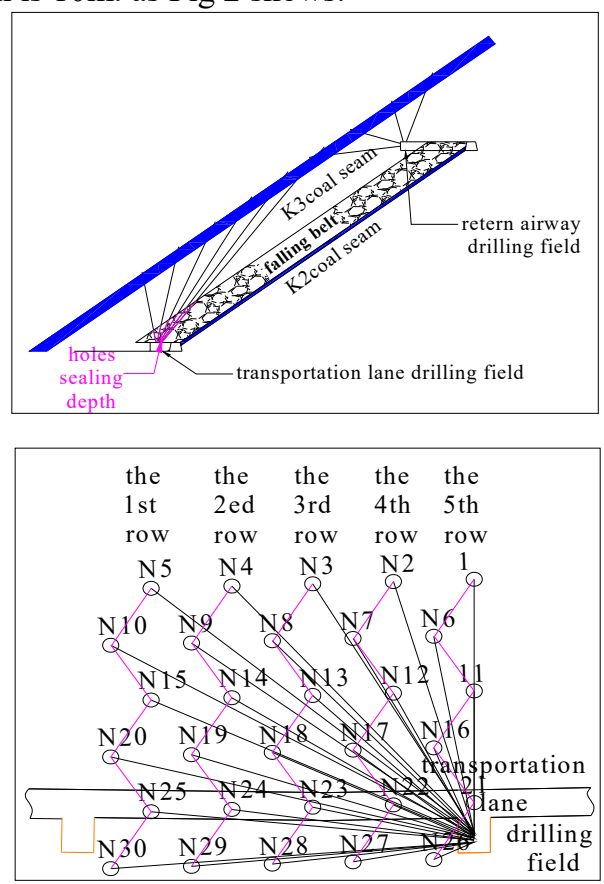

Fig $2 \mathrm{~K}_{3}$ b through layer sealing holes arrangement and depth in transportation drilling field 
(2)Specific practice: Inject a calculated length of 1.5-inch iron pipe into the borehole (the length of the iron pipe is $2 \mathrm{~m}$, two sets of wire is used, and the pipe hoop is connected, and the front end of the iron pipe $500 \mathrm{~mm}$ should be evenly arranged with not less than 15 holes with an aperture of $10 \mathrm{~mm}$ The length of the grouting pipe shall not be less than $6 \mathrm{~m}$. Using towel and $\mathrm{AB}$ rubber, the distance from the end of the pre-plugging section to the orifice is about 0.5 meters, and the length of the $\mathrm{AB}$ rubber plugging is about 0.5 meters. Then the grouting pump is used to fill the hole, and the sealing material is cement and Water without leakage, gypsum (ratio 10:1:1) mixture (feed mix ratio is controlled around 2.5:1).

\subsection{Sealing implementation}

No.2225 transportation lane 20\# drilling field constructed in early April and completed in late April. After completion of drilling holes, the pre-blockage was unified according to the "improvement plan" (pre-drilling depth was strictly calculated and determined in accordance with the sealing across Falling belts). After the completion of pre-blocking, uniform grouting is completed, the details as follow: the electric sealing pump and borehole grouting pipe are connected by DN15mm plastic pipe, and the cement, water is not leaked, and gypsum is filled in a slurry container with the ratios 10:1:1. Use BFK-15/2.4 electric type sealing pump (power $7.5 \mathrm{KW}$, flow rate $15 \mathrm{~L} / \mathrm{min}$ ) to drive the slurry into the hole. After returning slurry to the slurry, stop grouting and remove the connected plastic pipe, connect to the next drilling and grout, and complete the initial grouting in turn. After the first grouting is completed, a second grouting is performed. After returning the slush to each drilling hole, the grouting pipe is immediately picked up and tied with a rope to prevent the slush from flowing out of the grouting pipe. Two days after the completion of secondary grouting, the borehole was uniformly pumped and the extraction parameters were determined at regular intervals.

\subsection{Determination of extraction parameters}

No.2225 transportation lane 20\# drilling field $\mathrm{K}_{3}$ through hole adopts iron pipe sealing hole, and the relevant parameters of pre-pumping are determined regularly after the drilling site is connected. The gas drainage measured data are detailed in Table 2 and Table 3 during the initial mining of 2225 mining face.

Table2.Pre-extractionEffect in No.2225 Transportation 20\#Dirlling Field after Connected

\begin{tabular}{|c|c|c|c|}
\hline $\begin{array}{l}\text { Test } \\
\text { days }\end{array}$ & $\begin{array}{c}\text { pressure } \\
(\mathrm{Pa})\end{array}$ & $\begin{array}{c}\text { Concentration } \\
(\%)\end{array}$ & $\begin{array}{c}\text { Flow } \\
\left(\mathrm{m}^{3} / \mathrm{min}\right)\end{array}$ \\
\hline 4.26 & 5320 & 58 & 0.81 \\
\hline 5.6 & 2660 & 60 & 0.84 \\
\hline
\end{tabular}

\begin{tabular}{|c|c|c|c|}
\hline 5.16 & 2128 & 61 & 0.86 \\
\hline 6.8 & 2527 & 56 & 0.76 \\
\hline 7.8 & 2793 & 64 & 0.82 \\
\hline 8.10 & 2261 & 62 & 0.78 \\
\hline 9.12 & 2261 & 61 & 0.77 \\
\hline 10.8 & 2660 & 55 & 0.73 \\
\hline
\end{tabular}

Table3 Extraction Effect in No.2225 Mining Face Transportation 20\# Drilling Field At Initial Mining

\begin{tabular}{|c|c|c|c|c|}
\hline time & $\begin{array}{c}\text { Advanc } \\
\text { e rate } \\
(\mathbf{m})\end{array}$ & $\begin{array}{c}\text { Concentratio } \\
\mathbf{n} \\
\mathbf{( \% )}\end{array}$ & $\begin{array}{c}\text { Negative } \\
\text { pressure } \\
\mathbf{( P a )}\end{array}$ & $\begin{array}{c}\text { Drainage } \\
\text { amount } \\
\left(\mathbf{m}^{\mathbf{3}} / \mathbf{m i n}\right)\end{array}$ \\
\hline 10.25 & 12.2 & 52 & 2660 & 0.7 \\
\hline 10.26 & 12.9 & 78 & 2527 & 1.14 \\
\hline 10.27 & 13.8 & 75 & 2527 & 1.53 \\
\hline 10.28 & 14.6 & 80 & 2527 & 1.66 \\
\hline 10.29 & 15.5 & 80 & 2660 & 1.66 \\
\hline 10.30 & 16.4 & 81 & 2660 & 2.38 \\
\hline 11.2 & 19.2 & 80 & 4788 & 2.59 \\
\hline 11.3 & 19.8 & 81 & 2926 & 2.91 \\
\hline 11.4 & 20.4 & 73 & 2926 & 2.55 \\
\hline 11.5 & 21 & 73 & 2926 & 2.55 \\
\hline 11.6 & 21.9 & 83 & 2926 & 2.13 \\
\hline 11.7 & 22.5 & 85 & 2926 & 2.15 \\
\hline 11.8 & 22.5 & 75 & 2926 & 2.16 \\
\hline 11.9 & 22.5 & 80 & 2261 & 2.35 \\
\hline 11.10 & 22.8 & 76 & 2261 & 2.2 \\
\hline amount & 22.8 & & $/$ & \\
\hline & & \multicolumn{3}{|l}{} \\
\hline
\end{tabular}

\subsection{Drainage effect analysis}

According to the pre-extraction effect in 2225 transportation 20\#dirlling field after connected, it can obtain that:

(1) After the new process was used to seal the holes, the initial pumping concentration was higher, reaching $58 \%$, which was $19 \%$ higher than the original process, and the pre-pumping volume of the drill site reached $0.8 \mathrm{~m}^{3} / \mathrm{min}$, which was $60 \%$ higher than the original process. The effect of the improvement is obvious;

(2) After improving the sealing process, the pressure relief of the transportation lane will be higher and the concentration will be maintained between $70 \%$ and $80 \%$. The attenuation of the drainage volume will be slower and will be maintained at about $2 \mathrm{~m}^{3} / \mathrm{min}$. The cumulative extraction volume will reach $50,800 \mathrm{~m}^{3}$. 4.4 times the original process;

(3) Contrast the improvement cost of the $\mathrm{K}_{3} \mathrm{~b}$ through-hole sealing process in the transportation lane, as Table 4 shows. 
Table 4 Comparison of Costs of Main Sealing Materials for New and Old Processes

\begin{tabular}{|c|c|c|c|c|c|c|c|}
\hline \multicolumn{2}{|c|}{ New process (iron pipe seals across falling off belts) } & \multicolumn{3}{|c|}{ Original process (plastic pipe sealing hole 12m) } \\
\hline material & Unit price & quantity & $\begin{array}{c}\text { Total } \\
\text { amount } \\
\text { (RMB) }\end{array}$ & material & Unit price & quantity & $\begin{array}{c}\text { Total } \\
\text { amount } \\
(\mathrm{RMB})\end{array}$ \\
\hline Iron pipe & $18.8 \mathrm{yuan} / \mathrm{m}$ & $708 \mathrm{~m}$ & 13310 & Plastic pipe & $11.6 \mathrm{yuan} / \mathrm{m}$ & 360 & 4176 \\
\hline connector & $2 \mathrm{yuan} / \mathrm{a}$ & $62 \mathrm{a}$ & 124 & & & & \\
\hline cement & $295 \mathrm{yuan} / \mathrm{t}$ & $2 \mathrm{t}$ & 590 & cement & $295 \mathrm{yuan} / \mathrm{t}$ & $1 \mathrm{t}$ & 295 \\
\hline $\begin{array}{c}\text { Water } \\
\text { without } \\
\text { leakage }\end{array}$ & $7000 \mathrm{yuan} / \mathrm{t}$ & 0.12 & 840 & $\begin{array}{c}\text { Water } \\
\text { without } \\
\text { leakage }\end{array}$ & $7000 \mathrm{yuan} / \mathrm{t}$ & 0.06 & 420 \\
\hline \multicolumn{2}{|c|}{ Amount total with new process } & 14864 & $\begin{array}{c}\text { Amount total with original process } \\
4891\end{array}$ \\
\hline
\end{tabular}

\section{Conclusion}

(1)After the $\mathrm{K}_{3}{ }^{\mathrm{b}}$ coal seam through hole of the transportation lane shallow drilling field was changed from the plastic pipe sealing hole to the sealing hole depth of $8 \mathrm{~m}$ to the iron pipe sealing hole and the falling off belt, although the cost of the single hole sealing hole was increased by 2 times, the drainage effect was achieved. Improvement was obvious; the pre-drainage concentration in the drilling site increased by $19 \%$ to $58 \%$, the pre-pumping volume increased by $60 \%$ to $0.8 \mathrm{~m}^{3} / \mathrm{min}$, and the pressure relief drainage in the transportation lane was improved after the sealing technology was improved $70 \%-80 \%$. The amount of drainage was slowly attenuated and was maintained at about $2 \mathrm{~m}^{3} / \mathrm{min}$. The cumulative extraction volume was 5.08 million $\mathrm{m}^{3}$, which was 4.4 times that of the original process.

(2) Through the improvement of the $\mathrm{K}_{3} \mathrm{~b}$ seam through hole sealing technology, a good gas drainage effect has been achieved, which can be promoted and implemented in the whole mine in the future.

\section{Acknowledgement}

This research paper was supported by LongDong University Science Foundation for youth (XYZK1701)

\section{Reference}

1. Yang Kaifa. Analysis on Refuge Chamber Arrangement in Stope Face of Coal and Gas Outburst Mine [J]. Coal Engineering. 2014,46(06):17-18,22

2. Cheng Yuanping, Yu Qixiang,et al. Practice and Effectiveness of "Draining Gas before Coal Mining" to Prevent Gas from Bursting[J]. Journal of Mining \& Safety Engineering. 2006(04):389-392

3. Wang Haifeng, Cheng Yuanping, Yu Qixiang, et al. Research on the Amount of Safely Mineable Coal in Mines Susceptible to Coal and Gas Outburst[J]. Journal of China University of Mining \&
Technology. 2008(02):236-240

4. Sun Yuning, Wang Zhenfeng. New Sealing Technology of Cross Drilling Holes under Mining Influence [J]. Safety in Coal Mines. 2009 (09) :21-23

5. Cheng Yuanping, Fu Jianhua et al. Development of Gas Extraction Technology in Coal Mines of China $[\mathrm{J}]$. Journal of Mining \& Safety Engineering. 2009(02):127-139

6. $\mathrm{Hu}$ Po, Cheng Jun et al. Improvement and Application of Bedding Borehole Sealing Method [J]. Safety in Coal Mines. 2015(05):136-139

7. Xie Junxiang, Wang Hongsheng, et al. Numerical Calculation Method of Effective Drainage Radius for Gas Drainage Borehole [J]. Safety in Coal Mines. 2015(09):16-19

8. Wang Zhaofeng, Zhou Shaohua,et al. Determination Method for Borehole Bottom Location of Pressure-relief Gas Extraction Boreholes[J].Coal Engineering. 2011(06):82-84 